\title{
Pediatric Fibrinogen PART I-Pitfalls in Fibrinogen Evaluation and Use of Fibrinogen Replacement Products in Children
}

\author{
Elise J. Huisman ${ }^{1,2,3}$ and Gemma Louise Crighton ${ }^{4 *}$ \\ ${ }^{1}$ Department of Hematology, Erasmus Medical Center (MC) - Sophia Children's Hospital, Rotterdam, Netherlands, \\ ${ }^{2}$ Department of Clinical Chemistry and Blood Transfusion, Erasmus Medical Center (MC), Rotterdam, Netherlands, \\ ${ }^{3}$ Department of Transfusion Medicine, Sanquin Blood Supply, Amsterdam, Netherlands, ${ }^{4}$ Department of Hematology, Royal \\ Children's Hospital, Melbourne, VIC, Australia
}

Fibrinogen is a key coagulation protein, playing a critical role in hemostasis. It is the first factor to decrease to critical levels during bleeding. Hypofibrinogenemia is an important risk factor for bleeding in clinical settings, including pediatric surgery. Yet, the optimal measurement of fibrinogen levels is subject to debate, as is the critical threshold for intervention. Fibrinogen replacement may be provided by cryoprecipitate and fibrinogen concentrate. Whilst both products contain fibrinogen, they are not equivalent, each has its own advantages and disadvantages, especially for pediatric use. Unfortunately, medical literature to support fibrinogen replacement in children is limited. In this article we review the current diagnostic tools to measure fibrinogen, with respect to their use in the pediatric critical care setting. Secondly, we evaluate the different fibrinogen replacement therapies, focusing on cryoprecipitate and fibrinogen concentrate and examine their individual product characteristics, associated risks and benefits, different dosing strategies and specific pitfalls for use in children. We summarize by highlighting current knowledge gaps and areas for future research.

Keywords: children, intensive care, fibrinogen, hypofibrinogenemia, Clauss, viscoelastic testing, cryoprecipitate, fibrinogen concentrate

\section{INTRODUCTION}

This article was submitted to Pediatric Critical Care, a section of the journal

Frontiers in Pediatrics

Received: 14 October 2020

Accepted: 26 February 2021

Published: 21 April 2021

Citation:

Huisman EJ and Crighton GL (2021) Pediatric Fibrinogen PART I-Pitfalls in

Fibrinogen Evaluation and Use of Fibrinogen Replacement Products in Children. Front. Pediatr. 9:617500. doi: 10.3389/fped.2021.617500

Fibrinogen (Factor I) is a key coagulation protein and plays a critical role in all aspects of normal hemostasis: from platelet aggregation, to clot formation, and fibrinolysis $(1,2)$. During major surgical bleeding, fibrinogen is the first hemostatic factor to decrease to critical levels (3). Fibrinogen has been identified as an important risk factor for bleeding in children undergoing surgery (4-6).

As an acute phase reactant, fibrinogen plays a pivotal role in tissue repair and maintaining hemostasis during tissue injury and inflammation (7). Levels are often elevated in children in the context of fever, sepsis and critical illness (8-10). However, if hypofibrinogenemia is present in critically ill children with sepsis, it is associated with increased in-hospital mortality $(8,9)$.

See "Pediatric Fibrinogen PART II-Overview of Indications for Fibrinogen Use in Critically Ill Children", for further information about the clinical indications for fibrinogen supplementation in children. 


\section{Fibrinogen Evaluation and Specific Pitfalls in the Pediatric Setting}

The gold-standard for fibrinogen quantification is the clot-based Clauss fibrinogen assay. The Clauss-assay is a functional test that measures the time taken for plasma to clot in a high concentration of thrombin, with comparison against a reference plasma calibration curve (11). Patient factors that can impact the accuracy of the test include the presence of heparin and fibrinogen-degradation products (12). Similarly photo-optical clot detection systems for measuring fibrinogen may be affected by lipemia or hyperbilirubinemia (11). Hydroxyethyl starch (HES), a plasma volume expander used in some pediatric perioperative settings (13), can impair fibrin polymerization (13, 14) causing falsely reduced fibrinogen levels $(6,14)$. Additionally, direct thrombin inhibitors such as bivalirudin and argatroban can inhibit the thrombin used in the Clauss-assay causing falsely reduced levels (15).

Fibrinogen may also be evaluated by viscoelastic testing. The two most commonly used and evaluated in clinical trials in children are thromboelastography $\left(\mathrm{TEG}^{\circledR}\right)$ and thromboelastometry $\left(\mathrm{ROTEM}^{\circledR}\right)$. A qualitative indication of fibrinogen is obtained by inhibiting the platelet contribution to clot formation using cytochalasin D for ROTEM-FIBTEM and abciximab for TEG functional fibrinogen (TEG-FF) assay (16).

Whilst both TEG and ROTEM are based on similar methodologies, there are significant differences in operating characteristics, activators used, reporting nomenclature, and reference ranges. Parameters reported by each of the devices are not equivalent or interchangeable (16). One such example, is the measurement of hyperfibrinolysis, the TEG lysis index is measured $30 \mathrm{~min}$ after the maximum amplitude (MA), whereas the ROTEM lysis index is measured 30 min after the clotting time (17).

Viscoelastic measures of fibrinogen have benefits over the Clauss assay, since they are point-of-care test with quick turnaround times (16). Since they are performed using whole blood, they provide a global and visual hemostatic evaluation of hemostasis, from clot initiation and kinetics, through to clot degradation and fibrinolysis.

In the pediatric setting the usefulness and uptake of viscoelastic testing remains limited. There is a lack of standardization, with a scarcity of age-dependent reference ranges for the different reagents used with each viscoelastic method $(18,19)$. Studies are needed to define clear thresholds and targets for treatment in neonates and children (17). The maximum clot strength thresholds (Maximum Clot Firmness [MCF] for ROTEM or MA for TEG) that indicate the need for fibrinogen supplementation are debated. In addition, validated treatment algorithms using viscoelastic testing and fibrinogen supplementation are needed for the different neonatal and pediatric contexts (17).

Viscoelastic testing in infants and neonates may also be limited by the blood sample requirements; ROTEM requires at least $1.8 \mathrm{~mL}$ of whole blood and TEG $2.7 \mathrm{~mL}$ (20) although newer viscoelastic devices have smaller minimum sample requirements (17). Another limitation is that viscoelastic tests are unable to detect congenital bleeding disorders, such as platelet function disorders or von Willebrand disease (17).

Other techniques for measuring fibrinogen include Prothrombin-time (PT) derived tests, immunohematological assays (11), the dry-hematology method (21), and thrombin generation assays. These tests are not widely used or only available in research settings (22).

The fibrinogen level obtained will vary depending on the fibrinogen assay used (23). In adults, fibrinogen levels using the Clauss assay are typically reported between 150 and $450 \mathrm{mg} / \mathrm{dL}$, but physiological variation is commonly seen. In children, age-related reference ranges are required for fibrinogen quantification, because of the age-dependency (the so called developmental hemostasis) in hemostatic proteins (24). The lowest fibrinogen levels are reported in fetuses and preterm neonates $(25-27)$, and infants $(28,29)$. Similarly, there are agedependent differences seen in viscoelastic testing results $(19,30-$ 32). Pediatric age-specific reference ranges have been described for ROTEM parameters across pediatric age groups, including FIBTEM $(31,33)$ and for the TEG $(19,34)$.

Children also have qualitative differences in both fibrinogen and fibrinolysis (35). Neonates have a "fetal" form of fibrinogen (35), an altered fibrin network and clot structure (36), with an overall reduction in fibrinolytic activity (37), and often physiologically elevated D-dimers in the first $72 \mathrm{~h}$ of life (38).

The sensitivity of each fibrinogen assay refers to the lowest detectable and quantifiable amount of fibrinogen. The lowest reportable fibrinogen level will vary between individual laboratories but will be reported as less than a certain threshold, e.g., $<50 \mathrm{mg} / \mathrm{dL}$. In neonates, this can be rather imprecise, because physiological values can be this low.

In summary, fibrinogen reference ranges vary depending on the test, the analyzer and reagents used, in addition to the age of the child, therefore it is important that local, assay-specific and age-specific reference ranges are developed. Utilization of adult reference intervals, particularly in the neonates has the potential to lead to overtreatment. A normal physiological (low) fibrinogen level in a non-bleeding, preterm neonate, for example, does not need correction.

\section{FIBRINOGEN SUPPLEMENTATION}

Cryoprecipitate and fibrinogen concentrate both effectively restore fibrinogen levels $(39,40)$, and are used in children to provide fibrinogen replacement during active bleeding or as prophylaxis to prevent bleeding $(41,42)$. Internationally there is variability in practice regarding the favored fibrinogen replacement product, reflecting local legislation, licensing and product availability.

\section{Cryoprecipitate}

In the United States (US), Canada, United Kingdom (UK), Australia and New Zealand, cryoprecipitate is the main component available for treatment of acquired hypofibrinogenemia since fibrinogen concentrate is only licensed for the treatment of congenital fibrinogen deficiency (43). 


\section{Fibrinogen Concentrate}

In contrast, many European countries favor fibrinogen concentrate over cryoprecipitate for all therapeutic uses due to its superior pathogen safety profile and cryoprecipitate has been withdrawn due to safety concerns, principally transfusion transmitted infection (TTI) and prions. Fibrinogen concentrate in Europe is licensed for treatment of both congenital and acquired hypofibrinogenemia (43).

Whilst cryoprecipitate and fibrinogen concentrate are both plasma-derived products, there are considerable differences between the two products (see Table 1).

\section{Plasma Transfusion}

Plasma is the liquid component of blood that contains coagulation factors and coagulation inhibitors. Plasma products available include plasma frozen within $6-8 \mathrm{~h}$ of collection (FFP), plasma frozen within $24 \mathrm{~h}$ of collection, thawed plasma, liquid plasma and pathogen-inactivated plasma (44-46). Freeze-dried (lyophilized) or spray-dried plasma is largely restricted to military and research settings (47).
In the pediatric setting however, none of these plasma products, are suitable as fibrinogen replacement products since fibrinogen concentrations in plasma are very low and can vary considerably $(100-500 \mathrm{mg} / \mathrm{dL})(48,49)$. Large volumes of plasma are required to replenish a low or falling fibrinogen level (43), placing a child at significant risk of transfusion-associated circulatory overload (TACO).

In summary, cryoprecipitate and fibrinogen concentrate are superior to plasma as fibrinogen replacement products since they are concentrated products. We therefore will focus this review on these two fibrinogen products.

\section{PRODUCT CHARACTERISTICS}

\section{Product Characteristics of Cryoprecipitate}

Cryoprecipitate is the unpurified, cold-insoluble protein or "cryoglobulin" proportion derived from plasma. Cryoprecipitate may be manufactured as single apheresis units or pooled from multiple donors with varying volume size. It is stored

TABLE 1 | Comparison of Cryoprecipitate and Fibrinogen Concentrate (RiaSTAP ${ }^{\circledR} /$ Haemocomplettan ${ }^{\circledR}$ CSL Behring).

Cryoprecipitate (1-8)

Apheresis single donor or pooled from multiple donors

Many countries only use male plasma donors to reduce the risk

of TRALI.

Content

Fibrinogen, vWF, FVIII, FXIII

Platelet microparticles

Fibronectin

Anticoagulant-e.g., citrate-phosphate-dextrose or ACD

Presentation

Storage

Compatibility

Reconstitution

Speed of preparation

Administration

Shelf life

Fibrinogen content

Pediatric infusion

Pathogen-reduction and viral inactivation procedures

Adverse events

Surveillance

Costs per gram

fibrinogen massive transfusion)
Yellow, frozen cold-insoluble precipitate

$-25^{\circ} \mathrm{C}$ of below for a maximum of 3 years

$\mathrm{ABO}$ compatibility with recipient's red cells suggested

Thawed at $37^{\circ} \mathrm{C}$

17-20 min to thaw

Standard blood administration set with a 170-200 micron filter. Used within $4 \mathrm{~h}$ after thawing at room temperature

Variable fibrinogen content depending on fibrinogen content and cryoprecipitate volume

Range from 300 to $3,000 \mathrm{mg} / \mathrm{dL}$

$10-20 \mathrm{ml} / \mathrm{kg} / \mathrm{h}$

Pathogen- reduced plasma-Photoactivation by visible or UV light, solvent-detergent treatment, or the addition of chemicals to the plasma: methylene blue (MB), amotosalen or riboflavin. Results in 65-84\% lower fibrinogen content.

Risk of transfusion-transmitted infection

Allergic transfusion reaction and anaphylaxis

Febrile non-hemolytic transfusion reactions

TRALI

Citrate-induced hypocalcemia (increased risk with

Hemovigilance

$\sim$ AUD $\$ 480$ per gram

Higher costs when cryoprecipitate is produced from

pathogen-reduced plasma.
Pharmacovigilance

Fibrinogen concentrate (RiaSTAP ${ }^{\circledR} /$ Haemocomplettan ${ }^{\circledR}$ ) (8-11)

Pooled from $>10,000$ plasma donors.

Fibrinogen

Albumin

L-arginine $\mathrm{HCL}$

White lyophilized powder

$2-6^{\circ} \mathrm{C}$ for up to 5 years

No compatibility requirements

Sterile water for reconstitution at room temperature

5-10 min

Direct intravenous infusion by separate infusion line

Stable for $8 \mathrm{~h}$ after reconstitution when stored at room temperature Standardized fibrinogen content $-1,000 \mathrm{mg} / \mathrm{vial}$ and $2,000 \mathrm{mg} / \mathrm{vial}$

Slow IV infusion, not exceeding $100 \mathrm{mg} / \mathrm{min}$

$\mathrm{Al}(\mathrm{OH})_{3}$ adsorption/glycine precipitation /Al(OH $)_{3}$ adsorption Heat treatment at $60^{\circ} \mathrm{C}$ for $20 \mathrm{~h}$

Glycine precipitation

Allergic reactions and anaphylaxis

Infusion related adverse events

Thromboembolic complications

$\sim$ AUD $\$ 817$ per gram

ACD, acid-citrate-dextrose; FVIII, factor VIII; FXIII, factor XIII; HCL, hydrochloride; IV, intravenous; TRALI, transfusion-associated acute lung injury; UV, ultraviolet; vWF, von Willebrand factor. 
TABLE 2 | International standard product specifications for cryoprecipitate.

\begin{tabular}{|c|c|c|c|c|c|c|}
\hline & \multicolumn{2}{|c|}{ Fibrinogen (mg) per unit } & \multirow{2}{*}{$\begin{array}{c}\text { FVIII (IU) per unit } \\
\quad \geq 80\end{array}$} & \multirow{2}{*}{$\begin{array}{l}\text { FXIII (IU) per unit } \\
\geq 80\end{array}$} & \multirow{2}{*}{$\begin{array}{l}\text { VWF per unit } \\
\geq 80\end{array}$} & \multirow{2}{*}{$\begin{array}{l}\text { Volume } \\
\text { Maximum } 15 \mathrm{~mL}\end{array}$} \\
\hline United States $(1,2)$ & $\geq 150^{\mathrm{a}}$ & & & & & \\
\hline EDQM Standards 2020 (3) & $\geq 140$ & & $\geq 70$ & Not specified & $\geq 100$ & $30-40 \mathrm{~mL}$ \\
\hline & Pool (5 donors) & $\geq 700$ & $\geq 350$ & & & $100-250 \mathrm{~mL}^{\mathrm{e}}$ \\
\hline
\end{tabular}

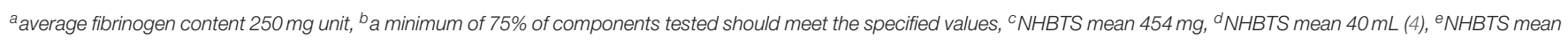
$221 \mathrm{ml}$.

as a frozen product and inventoried by blood group. It contains fibrinogen in addition to coagulation factors VIII (FVIII), von Willebrand factor (vWF), factor XIII (FXIII), as well as fibronectin and platelet microparticles (45). Cryoprecipitate was originally used therapeutically in the treatment of hemophilia $\mathrm{A}$, and then von Willebrand disease (vWD), congenital fibrinogen and FXIII deficiency (50). Today cryoprecipitate is predominantly utilized to replace fibrinogen in acquired hypofibrinogenemia.

Internationally, specific product requirements for the manufacture of cryoprecipitate vary between countries with respect to the minimum fibrinogen, FVIII and vWF concentrations (44) (see Table 2). Whilst minimum fibrinogen content per unit is usually specified by standards (e.g., $>140$ $\mathrm{mg} / \mathrm{unit})(45,46)$, the actual concentration can vary considerably (300-3,000 mg/dL), due to differences in blood donor fibrinogen levels, varying manufacturing processes and different unit volumes (51).

Advantages and disadvantages of cryoprecipitate in comparison with fibrinogen concentrate are described in Table $\mathbf{1 .}$

One potential clinical advantage of cryoprecipitate is the contribution of FXIII in the treatment of bleeding, especially in the surgical setting (52-54). In-vitro studies have shown that cryoprecipitate reverses fibrinolysis better than fibrinogen concentrate (55). A second consideration is cost: when evaluated per gram of fibrinogen, cryoprecipitate is cheaper $(56,57)$, even when economic analysis has considered preparation and wastage costs (58). However, this advantage may not be as notable with pathogen-reduced cryoprecipitate, since pathogen-inactivation comes with additional costs.

An important downside of cryoprecipitate is the risk of pathogen transmission, even with appropriate blood donor and donation screening (59). Cryoprecipitate made from pathogenreduced plasma can reduce this risk (60-62) and this is the preferred product for the treatment of congenital bleeding disorder in resource-limited settings $(60,61)$. Unfortunately, pathogen-inactivation results in reduced fibrinogen levels (65$84 \%$ ) of normal plasma (62). To overcome this, it may be possible to increase the number of donors contributing to the plasma pool or increase the transfusion volume $(63,64)$.

Cryoprecipitate has been implicated in a number of transfusion-related adverse events including allergic reactions, febrile, non-hemolytic transfusion reactions $(65,66)$ as well as transfusion-associated acute lung injury (TRALI) $(67,68)$ and TTI $(59,69)$. There is also evidence that adverse transfusion reactions occur more frequently in children compared with adult $(66,70)$. Any patient receiving cryoprecipitate must be monitored for a transfusion reaction and any incidents should be reported to the local hemovigilance reporting system. To maintain traceability, the blood compatibility report should be maintained in the child's medical record.

Cryoprecipitate is less suited to the acute pediatric critical care setting since it requires thawing prior to administration, and once thawed, it has a shelf life of $4 \mathrm{~h}$, after which it must be discarded (46). To overcome this, it would be ideal to keep "ready for-use" units of unthawed cryoprecipitate. In-vitro studies evaluating thawed pathogen-reduced cryoprecipitate, held at room temperature for 5 days have demonstrated its ability to restore fibrinogen levels and clot strength (FIBTEM) (63). However, in the pediatric setting di (2-ethylhexyl)phthalate (DEHP) toxicity should be considered (71). DEHP is a chemical added to plastics to make them more flexible and is commonly used in blood bags (72). DEHP levels increase in concentration as blood storage duration is increased (71). Toxic and carcinogenic effects are seen in animal studies, but the evidence for toxicity in humans has not been established, but remains a concern in neonates (72).

\section{Product Characteristics of Fibrinogen Concentrate}

Fibrinogen concentrate is a purified, virus-inactivated, lyophilized concentrate derived from pooled human plasma. It comes as a powder that can be reconstituted with sterile water (within 5-10 min) to deliver a reliable and standardized fibrinogen content $(73,74)$. In children with hypofibrinogenemia, fibrinogen concentrate has a rapid onset of action and is effective at increasing fibrinogen levels $(39,40)$.

There are a number of fibrinogen concentrates available internationally. The one most widely used is Haemocomplettan $\mathrm{P}^{\circledR} /$ RiaSTAP ${ }^{\circledR}$ (CSL Behring) (43) which contains between 900 and $1,300 \mathrm{mg}$ of fibrinogen $/ 50 \mathrm{~mL}(74,75)$. Other available fibrinogen concentrates include: Clottafact ${ }^{\circledR}$ (LFB Biomedicaments) (76), FibCLOT ${ }^{\circledR}$ (LFB Biopharmaceuticals Ltd.) (77) and Fibryga ${ }^{\circledR} /$ Octafibrin ${ }^{\circledR}$ (Octapharma) (78) and locally produced Fibrinogen HT (Japan) and FibroRAAS/FabuLaishi (China) (79). These fibrinogen concentrates are not all equivalent, they differ in: pathogen reduction strategies (80), fibrinogen concentrations, formulations (for example Fibryga ${ }^{\circledR}$ Octapharma contains more FXIII) (81, 82), stability agents and constituents, storage requirements and reconstitution stability data, and finally, in varying pediatric dosing recommendations $(43,74,76-78,81,83,84)$ (see Table 3$)$ for the full overview.

An overview of the advantages and disadvantages of fibrinogen concentrate compared with cryoprecipitate are 
TABLE 3 | Comparison between fibringeon concentrate products.

\begin{tabular}{|c|c|c|c|}
\hline & RiaSTAP ${ }^{\circledR} /$ Haemocomplettan $\mathrm{P}^{\circledR}(1-3)$ & Fibryga ${ }^{\circledR} /$ Octafibrin ${ }^{\circledR}(4,5)$ & Clottafact ${ }^{\circledR} /$ FibCLOT $^{\circledR}$ (6-9) \\
\hline Manufacturer & CSL Behring, Germany & Octapharma, Switzerland & LFB Biomedicaments, France \\
\hline Pathogen reduction & $\begin{array}{l}\mathrm{Al}(\mathrm{OH})_{3} \text { adsorption/glycine precipitation } \\
/ \mathrm{Al}(\mathrm{OH})_{3} \text { adsorption } \\
\text { Heat treatment at } 60^{\circ} \mathrm{C} \text { for } 20 \mathrm{~h} \\
\text { Glycine precipitation }\end{array}$ & $\begin{array}{l}\mathrm{Al}(\mathrm{OH})_{3} \text { adsorption } \\
\text { Solvent-detergent treatment } \\
\text { Nanofiltration }(20 \mathrm{~nm})\end{array}$ & $\begin{array}{l}\text { Solvent-detergent treatment } \\
\text { Nanofiltration }(35 \mathrm{~nm}) \\
\text { Dry heat treatment at } 80^{\circ} \mathrm{C} \text { for } 20 \mathrm{~h}\end{array}$ \\
\hline Vial size & 1,000 and $2,000 \mathrm{mg}$ & $1,000 \mathrm{mg}$ & $1,500 \mathrm{mg}$ \\
\hline Stability agents & $\begin{array}{l}\text { Albumin } \\
\text { L-arginine HCL } \\
\text { Sodium chloride } \\
\text { Sodium citrate }\end{array}$ & $\begin{array}{l}\text { Glycine } \\
\text { L-arginine HCL } \\
\text { Sodium chloride } \\
\text { Sodium citrate dihydrate }\end{array}$ & $\begin{array}{l}\text { Glycine } \\
\text { Arginine } \mathrm{HCL} \\
\text { Isoleucine } \\
\text { Lysine } \mathrm{HCL} \\
\text { Sodium citrate dihydrate }\end{array}$ \\
\hline Pediatric Dosing & $\begin{array}{l}\text { Dose }(\mathrm{mg} / \mathrm{kg} \text { body weight) }=[\text { Target level } \\
(\mathrm{mg} / \mathrm{dL})-\text { measured level }(\mathrm{mg} / \mathrm{dL})] / 1.7 \\
(\mathrm{mg} / \mathrm{dL} \text { per } \mathrm{mg} / \mathrm{kg})\end{array}$ & $\begin{array}{l}\text { Dose }(\mathrm{mg} / \mathrm{kg} \text { body weight })=[\text { Target level } \\
(\mathrm{mg} / \mathrm{dL})-\text { measured level }(\mathrm{mg} / \mathrm{dL})] / 1.8 \\
(\mathrm{mg} / \mathrm{dL} \text { per } \mathrm{mg} / \mathrm{kg})\end{array}$ & $\begin{array}{l}\text { Dose }(\mathrm{mg})=[\text { Target level } \\
(\mathrm{mg} / \mathrm{dL})-\text { baseline level }(\mathrm{mg} / \mathrm{dL})] \times \\
1 / \mathrm{recovery}(\mathrm{mg} / \mathrm{dL}) /(\mathrm{mg} / \mathrm{kg}) \times \text { body weight } \\
(\mathrm{kg})\end{array}$ \\
\hline \multirow[t]{2}{*}{$\begin{array}{l}\text { Pediatric dosing when } \\
\text { fibrinogen level unknown }\end{array}$} & $\begin{array}{l}\text { RiaSTAP }^{\circledR} \\
70 \mathrm{mg} / \mathrm{kg} \text { for congenital } \\
\text { fibrinogen deficiency }\end{array}$ & \multirow[t]{2}{*}{$\begin{array}{l}60 \mathrm{mg} / \mathrm{kg} \text { for congenital fibrinogen } \\
\text { deficiency }\end{array}$} & \multirow[t]{2}{*}{$\begin{array}{l}\text { When } 1 / \text { recovery unknown } \\
53 \mathrm{mg} / \mathrm{kg} \text { for children }<40 \mathrm{~kg} \\
43 \mathrm{mg} / \mathrm{kg} \text { for children } \geq 40 \mathrm{~kg}\end{array}$} \\
\hline & $\begin{array}{l}\text { Haemocomplettan } P^{\circledR} \\
20-30 \mathrm{mg} / \mathrm{kg} \text { treatment for active bleeding } \\
\text { in children }\end{array}$ & & \\
\hline Pediatric infusion rates & $\begin{array}{l}\text { Slow IV infusion, not exceeding } 100 \\
\mathrm{mg} / \mathrm{min}\end{array}$ & $\begin{array}{l}\text { Slow IV infusion, maximum rate of } 100 \\
\mathrm{mg} / \mathrm{min} \text {. }\end{array}$ & $\begin{array}{l}\text { Clinically stable patients }-4 \mathrm{ml} / \mathrm{min}=60 \\
\mathrm{mg} / \mathrm{min} \\
\text { Severe acute hemorrhage }-20 \mathrm{ml} / \mathrm{min}= \\
300 \mathrm{mg} / \mathrm{min}\end{array}$ \\
\hline
\end{tabular}

HCL, hydrochloride; $I$, intravenous.

described in detail in Table 1. An advantage of fibrinogen concentrate for use in neonates and critically ill children is its relatively small infusion volume. Doses of fibrinogen concentrate are going to be in the order of $1-3.5 \mathrm{~mL} / \mathrm{kg}$ compared with $5-10 \mathrm{~mL} / \mathrm{kg}$ for cryoprecipitate. Fibrinogen may be able to be administered quicker than cryoprecipitate, depending on where it is stored in the hospital, since it only requires refrigeration for storage.

Fibrinogen concentrate also has a superior pathogen safety profile and low rates of adverse events. A pharmacosurveillance study of 27 years of Haemocomplettan $\mathrm{P}^{\circledR} /$ RiaSTAP $^{\circledR} \quad$ (CSL Behring) use with literature review, reported an excellent safety profile (85). Each fibrinogen concentrate administration be monitored for side effects and any reactions or adverse events be reported to the pharmacovigilance system. Each administration and the batch number must be recorded in the patient record to maintain traceability.

A relative disadvantage of use in neonates is that the dose required for treatment is much less than the smallest formulation of fibrinogen concentrate available $(1,000 \mathrm{mg})$, leading to product wastage and higher costs. For example, a dose of $30 \mathrm{mg} / \mathrm{kg}$ fibrinogen concentrate to treat hypofibrinogenemia in a $5 \mathrm{~kg}$ infant only equals $150 \mathrm{mg}$.
In summary, cryoprecipitate is a rich source of fibrinogen and includes other coagulation factors important for hemostasis. Cryoprecipitate is widely used in countries where fibrinogen concentrate is not licensed for use in acquired hypofibrinogenemia, and in resource-limited settings as therapy for congenital hypofibrinogenemia, although pathogen-inactivated cryoprecipitate is favored. Disadvantages are the large inter-unit variability of fibrinogen in cryoprecipitate, the increased risk of transfusion reactions and infectious transmission, in addition to the logistical and blood banking requirements.

Plasma-derived fibrinogen concentrates are able to rapidly and effectively restore and maintain serum fibrinogen concentrations. They are used for treatment of congenital and acquired hypofibrinogenemia. They have an excellent safety profile and are amenable to near-patient storage, which may reduce the time to administration. They come with a higher cost and generally do not contain additional hemostatic factors that may be important for general hemostasis.

\section{DOSING OF FIBRINOGEN SUPPLEMENTS}

\section{Dosing of Cryoprecipitate}

A standard treatment dose of cryoprecipitate in adults is 10 units or two pools (where one pool is made from five units), leading 
TABLE 4 | Guidance for dosing of cryoprecipitate and fibrinogen concentrate in children.

Cryoprecipitate dosing in children

\begin{tabular}{|c|c|c|}
\hline Guidance & Dosing & Dosing considerations \\
\hline $\begin{array}{l}\text { National Blood Authority of } \\
\text { Australia (NBA) (2) }\end{array}$ & $5 \mathrm{ml} / \mathrm{kg}$ for acquired hypofibrinogenemia & $\begin{array}{l}\text { Consider patient's clinical condition, the presence of active bleeding, } \\
\text { medications affecting coagulation status, and congenital and acquired } \\
\text { bleeding disorders. }\end{array}$ \\
\hline $\begin{array}{l}\text { British Society of } \\
\text { Hematology (BSH) (3) }\end{array}$ & $\begin{array}{l}5-10 \mathrm{ml} / \mathrm{kg} \text { of methylene blue cryoprecipitate } \\
\text { Higher doses for active bleeding and } \\
\text { acquired hypofibrinogenemia }\end{array}$ & $\begin{array}{l}\text { Lower fibrinogen content in methylene-blue cryoprecipitate } \\
\sim 250 \mathrm{mg} / \text { unit compared with } \sim 430 \mathrm{mg} / \mathrm{unit} \text { in a non-treated unit (4). }\end{array}$ \\
\hline $\begin{array}{l}\text { Rare bleeding disorder } \\
\text { guideline (64) }\end{array}$ & $\begin{array}{l}15-20 \mathrm{ml} / \mathrm{kg} \text { of pathogen reduced cryoprecipitate for } \\
\text { treatment of congenital fibrinogen disorders when fibrinogen } \\
\text { concentrate not available }\end{array}$ & $\begin{array}{l}\text { Fibrinogen concentrate is first line treatment for congenital fibrinogen } \\
\text { disorders }\end{array}$ \\
\hline $\begin{array}{l}\text { Society for the } \\
\text { Advancement of Blood } \\
\text { Management (SABM) (7) }\end{array}$ & $\begin{array}{l}\text { Cryoprecipitate volume should be calculated based on weight } \\
\text { and desired increase in fibrinogen concentration and } \\
\text { improvement in coagulations indices. }\end{array}$ & $\begin{array}{l}\text { The decision to transfuse should be based on laboratory studies } \\
\text { including point of care viscoelastic testing if available, fibrinogen } \\
\text { concentration, the patient's clinical status and the etiology of the } \\
\text { patient's coagulopathy. }\end{array}$ \\
\hline AABB (9) & $\begin{array}{l}\text { Calculated from formula } \\
\text { Dose }(\text { units })=\frac{\left[\text { desired fibrinogen increment }\left(\frac{m g}{d L}\right) \times \text { plasma volume }(d L)\right]}{250 m g} \\
\text { Plasma volume }(d L) \text { in children }= \\
\text { Total Blood volume }(m L) \times \frac{[1-\text { hematocrit }(\%)]}{100}\end{array}$ & $\begin{array}{l}\text { Takes into account the desired fibrinogen increment }(\mathrm{mg} / \mathrm{dL} \text { ), average } \\
\text { fibrinogen content per unit of } 250 \mathrm{mg} \text { and plasma volume of the child } \\
\text { (9). } \\
\text { Plasma and blood volumes vary in children. } \\
\text { Blood volumes in children may be estimated using the formula } \\
70 \mathrm{~mL} / \mathrm{kg} \text {, but this will underestimate the blood volume in a neonate } \\
\text { and overestimate the blood volume in an adolescent or overweight } \\
\text { child }(10,11)\end{array}$ \\
\hline $\begin{array}{l}\text { Blood Easy 4, Canada, } \\
2016 \text { (12) }\end{array}$ & $\begin{array}{l}1 \text { unit/10 kg body weight to a maximum of } 10 \text { units } \\
(\sim 4,000 \mathrm{mg} \text { fibrinogen) }\end{array}$ & $\begin{array}{l}\text { Each dose should increase the fibrinogen by } 50 \mathrm{mg} / \mathrm{dL} \text { in the bleeding } \\
\text { patient. }\end{array}$ \\
\hline NICE Guidelines 2015 (13) & $5-10 \mathrm{~mL} / \mathrm{kg}$ up to a maximum of two pools & $\begin{array}{l}\text { Reassess the patient's clinical condition, repeat the fibrinogen level } \\
\text { measurement, and give further doses if needed. }\end{array}$ \\
\hline
\end{tabular}

Fibrinogen concentrate dosing in children

\begin{tabular}{|c|c|c|}
\hline Pediatric dosing & Dosing & Dosing considerations \\
\hline $\begin{array}{l}\text { Riastap }{ }^{\circledR} \text { (CSL Behring, } \\
\text { Germany) (14) }\end{array}$ & $\begin{array}{l}\text { Congenital fibrinogen deficiency } \\
\text { Dose }\left(\frac{m g}{\mathrm{~kg}}\right)= \\
{\left[\text { Target fibrinogen level }\left(\frac{\mathrm{mg}}{\mathrm{dL}}\right) \text { - measured level }\left(\frac{\mathrm{mg}}{\mathrm{dL}}\right)\right]} \\
/ 1.7(\mathrm{mg} / \mathrm{dL} \text { per } \mathrm{mg} / \mathrm{kg} \text { body weight). }\end{array}$ & $70 \mathrm{mg} / \mathrm{kg}$ when patient's fibrinogen level is not known \\
\hline $\begin{array}{l}\text { Rare bleeding disorder } \\
\text { guideline (6) }\end{array}$ & $\begin{array}{l}\text { Congenital fibrinogen deficiency } \\
50-100 \mathrm{mg} / \mathrm{kg}\end{array}$ & $\begin{array}{l}\text { Smaller doses repeated every } 2-4 \text { days to maintain fibrinogen }>100 \\
\mathrm{mg} / \mathrm{dL}\end{array}$ \\
\hline Fibryga ${ }^{\circledR}$ Octapharma & $\begin{array}{l}\text { Congenital fibrinogen deficiency } \\
\text { Dose }\left(\frac{m g}{\mathrm{~kg}}\right)= \\
{\left[\text { Target fibrinogen level }\left(\frac{\mathrm{mg}}{\mathrm{dL}}\right) \text { - measured level }\left(\frac{\mathrm{mg}}{\mathrm{dL}}\right)\right]} \\
/ 1.8(\mathrm{mg} / \mathrm{dL} \text { per } \mathrm{mg} / \mathrm{kg} \text { body weight }\end{array}$ & $\begin{array}{l}60 \mathrm{mg} / \mathrm{kg} \text { when patient's fibrinogen level is not known } \\
\text { Monitor patient's fibrinogen level during treatment }\end{array}$ \\
\hline $\begin{array}{l}\text { Haemocomplettan } \mathrm{P}^{\circledR}(\mathrm{CSL} \\
\text { Behring, Germany) (15) }\end{array}$ & $\begin{array}{l}\text { Acquired hypofibrinogenemia } \\
20-30 \mathrm{mg} / \mathrm{kg}\end{array}$ & \\
\hline
\end{tabular}

to an increase of $100 \mathrm{mg} / \mathrm{dL}$ fibrinogen (86). In children, dosing for both prophylactic and therapeutic cryoprecipitate indications should be calculated at least taking into account the child's weight (87). Most pediatric transfusion guidelines dose cryoprecipitate based on the child's weight as a single variable $(88,89)$. Many advise doses of 5 and $10 \mathrm{~mL} / \mathrm{kg}$ (88-91), with exceptions of $20 \mathrm{~mL} / \mathrm{kg}$ for the treatment of congenital fibrinogen deficiency with pathogen-reduced cryoprecipitate (64) (see Table 4).
However, more complex formulas will take into account a child's baseline fibrinogen level, the desired fibrinogen level, the average fibrinogen content of the local cryoprecipitate unit and a child's plasma volume (92) (see Table 4).

In general, blood volumes in children may be estimated using the formula $70 \mathrm{~mL} / \mathrm{kg}(93,94)$. However, this equation underestimates the blood volume for a neonate, since the estimated blood volume (EBV) decreases with age, from around 
$90-100 \mathrm{~mL} / \mathrm{kg}$ in preterm infants to $\sim 80 \mathrm{~mL} / \mathrm{kg}$ in term infants (93) and overestimates the blood volume in obese, post-pubertal adolescents $(\sim 60-70 \mathrm{~mL} / \mathrm{kg})$. None of these calculations corrects for ethnic differences and social factors such as malnutrition or obesity which may be important (94).

Dosing of cryoprecipitate in children should also consider the fibrinogen content of local products, particularly with pathogenreduced cryoprecipitate $(92,95,96)$.

The half-life of fibrinogen is relatively long (3-4 days) (64), and therefore, usually one dose is sufficient for prophylactic indications, however in the presence of active bleeding with ongoing loss or a poor fibrinogen increment, additional doses may be required.

\section{Dosing of Fibrinogen Concentrate}

Fibrinogen concentrate is dosed by most clinical guidelines in $\mathrm{mg} / \mathrm{kg}$. But here also, more complex formulas are seen, taking target and measured fibrinogen levels into the equation (see Table 4).

For each of the other available fibrinogen concentrates on the market, there are different dosing recommendations for children, and it is therefore recommended to consult the individual product information for specific dosing advice (see Table 3 ).

In summary, the dosing of cryoprecipitate is influenced by both donor and product variables. The dosing of both cryoprecipitate and fibrinogen concentrate in children should be calculated, taking into consideration the baseline fibrinogen, the child's body weight, the presence of active bleeding and ongoing loss. It is advisable, that after fibrinogen supplementation, both the clinical response to treatment and fibrinogen levels are re-evaluated to assess for any additional requirements.

\section{CURRENT KNOWLEDGE GAPS, CONTROVERSIES, AND AREAS FOR RESEARCH}

The decision to supplement fibrinogen firstly relies on adequate measurement of fibrinogen. When evaluating fibrinogen levels and function in the critically ill child, it is important to consider the accuracy of the result, the clinical context, the specific reference ranges and each test's limitations.

When fibrinogen replacement is indicated in critically ill children, there remain many uncertainties regarding the best choice of fibrinogen replacement, the optimal dose, in addition to the target or desired fibrinogen level. Each product has its own set of limitations and benefits specific to children.

The following questions, may be proposed as potential areas for research in neonates, including those preterm, infants, children, and adolescents.

In the area of laboratory testing:

- Can we develop small-volume tests for measuring fibrinogen in neonates and critically ill children?
- How do different viscoelastic measures of fibrinogen function compare with clot based Clauss fibrinogen assays in children?

Fibrinogen and bleeding

- How do age-dependent coagulation differences influence bleeding in neonates and children?

- In particular, what effect does the presence of fetal fibrinogen and altered fibrin clot structure have on fibrinogen function in preterm and term neonates?

Fibrinogen replacement products

- What is the optimal fibrinogen replacement component in children?

- What role does the additional FXIII, vWF, and FVIII in cryoprecipitate play in treating and preventing bleeding in children with a low fibrinogen?

- How do fibrinogen concentrate products that contain FXIII compare with those that do not?

- What is the optimal formula to dose fibrinogen in children?

- What is the optimal dose and timing in children of cryoprecipitate and fibrinogen concentrate

$\circ$ for the prevention of bleeding?

$\circ$ for the treatment of active bleeding?

Adverse events:

- How do we capture and report adverse events related to fibrinogen supplementation in children?

\section{CONCLUSIONS}

Hypofibrinogenemia is increasingly recognized as an important risk factor for bleeding and there has been an increasing focus on the fibrinogen supplementation by clinicians and clinical guidelines. Yet, there are many unknowns. The decision to supplement fibrinogen firstly relies on adequate measurement of fibrinogen and there are many pitfalls around the optimal fibrinogen measurement in children. Cryoprecipitate and fibrinogen concentrate both effectively restore fibrinogen levels, but each product has its own set of advantages and constraints specific to use in children. Fibrinogen concentrate is an attractive alternative to cryoprecipitate, offering a superior safety profile, with apparent efficacy, but not every fibrinogen concentrate product is equivalent. Further randomized controlled evidence is required to support decisionmaking regarding fibrinogen supplementation in children, including those who are critically ill.

\section{AUTHOR CONTRIBUTIONS}

GC literature review, writing, and editing article. EH reviewing content and editing article. All authors contributed to the article and approved the submitted version. 


\section{REFERENCES}

1. Velik-Salchner C, Haas T, Innerhofer P, Streif W, Nussbaumer W, Klingler A, et al. The effect of fibrinogen concentrate on thrombocytopenia. J Thromb Haemost. (2007) 5:1019-25. doi: 10.1111/j.1538-7836.2007.02481.x

2. Mosesson MW, Siebenlist KR, Meh DA. The structure and biological features of fibrinogen and fibrin. Ann N Y Acad Sci. (2001) 936:1130. doi: 10.1111/j.1749-6632.2001.tb03491.x

3. Hiippala ST, Myllyla GJ, Vahtera EM. Hemostatic factors and replacement of major blood loss with plasma-poor red cell concentrates. Anesth Analg. (1995) 81:360-5. doi: 10.1213/00000539-199508000-00026

4. Fries D, Martini WZ. Role of fibrinogen in trauma-induced coagulopathy. $\mathrm{Br}$ J Anaesth. (2010) 105:116-21. doi: 10.1093/bja/aeq161

5. Ranucci M, Bianchi P, Cotza M, Beccaris C, Silvetti S, Isgro G, et al. Fibrinogen levels and postoperative chest drain blood loss in low-weight $(<10 \mathrm{~kg})$ children undergoing cardiac surgery. Perfusion. (2019) 34:62936. doi: $10.1177 / 0267659119854246$

6. Faraoni D, Willems A, Savan V, Demanet H, De Ville A, Van der Linden P. Plasma fibrinogen concentration is correlated with postoperative blood loss in children undergoing cardiac surgery. A retrospective review. Eur J Anaesthesiol. (2014) 31:317-26. doi: 10.1097/EJA.0000000000000043

7. Luyendyk JP, Schoenecker JG, Flick MJ. The multifaceted role of fibrinogen in tissue injury and inflammation. Blood. (2019) 133:51120. doi: 10.1182/blood-2018-07-818211

8. Niederwanger C, Bachler M, Hell T, Linhart C, Entenmann A, Balog $\mathrm{A}$, et al. Inflammatory and coagulatory parameters linked to survival in critically ill children with sepsis. Ann Intensive Care. (2018) 8:111. doi: 10.1186/s13613-018-0457-8

9. Tang X, Shao L, Dou J, Zhou Y, Chen M, Cui Y, et al. Fibrinogen as a prognostic predictor in pediatric patients with sepsis: a database study. Mediators Inflamm. (2020) 2020:9153620. doi: 10.1155/2020/9153620

10. Bucak IH, Almis H, Turgut M. Evaluation of platelet parameters and acute phase reactants in pediatric patients presenting with fever. J Pediatr Inf. (2019) 13:e103-e7. doi: 10.5578/ced.68125

11. Mackie IJ, Kitchen S, Machin SJ, Lowe GD, Haemostasis and Thrombosis Task Force of the British Committee for Standards in Haematology. Guidelines on fibrinogen assays. Br J Haematol. (2003) 121:396-404. doi: 10.1046/j.1365-2141.2003.04256.x

12. Stang LG, Mitchell LG. Chapter 14: Fibrinogen. In: Monagle P, editor. Haemostasis: Methods and Protocols. New York, NY: Springer Science + Business Media (2013). p. 181-92.

13. Thy M, Montmayeur J, Julien-Marsollier F, Michelet D, Brasher C, Dahmani S, et al. Safety and efficacy of peri-operative administration of hydroxyethyl starch in children undergoing surgery: A systematic review and metaanalysis. Eur J Anaesthesiol. (2018) 35:484-95. doi: 10.1097/EJA.0000000000 000780

14. Kozek-Langenecker SA. Effects of hydroxyethyl starch solutions on hemostasis. Anesthesiology. (2005) 103:65460. doi: 10.1097/00000542-200509000-00031

15. Molinaro RJ, Szlam F, Levy JH, Fantz CR, Tanaka KA. Low plasma fibrinogen levels with the Clauss method during anticoagulation with bivalirudin. Anesthesiology. (2008) 109:160-1. doi: 10.1097/ALN.0b013e31817885b7

16. Whiting D, DiNardo JA. TEG and ROTEM: technology and clinical applications. Am J Hematol. (2014) 89:228-32. doi: 10.1002/ajh.23599

17. Haas T, Faraoni D. Viscoelastic testing in pediatric patients. Transfusion. (2020) 60(Suppl. 6):S75-85. doi: 10.1111/trf.16076

18. Ryan ML, Van Haren RM, Thorson CM, Andrews DM, Perez EA, Neville HL, et al. Trauma induced hypercoagulablity in pediatric patients. J Pediatr Surg. (2014) 49:1295-9. doi: 10.1016/j.jpedsurg.2013.11.050

19. Chan KL, Summerhayes RG, Ignjatovic V, Horton SB, Monagle PT. Reference values for kaolin-activated thromboelastography in healthy children. Anesth Analg. (2007) 105:1610-3. doi: 10.1213/01.ane.0000287645.26763.be

20. Rizoli S, Min A, Sanchez AP, Shek P, Grodecki R, Veigas P, et al. In trauma, conventional ROTEM and TEG results are not interchangeable but are similar in clinical applicability. Mil Med. (2016) 181(Suppl. 5):11726. doi: 10.7205/MILMED-D-15-00166

21. Ogawa S, Tanaka KA, Nakajima Y, Nakayama Y, Takeshita J, Arai M, et al. Fibrinogen measurements in plasma and whole blood: a performance evaluation study of the dry-hematology system. Anesth Analg. (2015) 120:1825. doi: 10.1213/ANE.0000000000000448

22. van Veen JJ, Gatt A, Makris M. Thrombin generation testing in routine clinical practice: are we there yet? Br J Haematol. (2008) 142:889903. doi: 10.1111/j.1365-2141.2008.07267.x

23. Lowe GD, Rumley A, Mackie IJ. Plasma fibrinogen. Ann Clin Biochem. (2004) 41(Pt 6):430-40. doi: 10.1258/0004563042466884

24. Attard C, van der Straaten T, Karlaftis V, Monagle P, Ignjatovic V. Developmental hemostasis: age-specific differences in the levels of hemostatic proteins. J Thromb Haemost. (2013) 11:1850-4. doi: 10.1111/jth.12372

25. Christensen RD, Baer VL, Lambert DK, Henry E, Ilstrup SJ, Bennett ST. Reference intervals for common coagulation tests of preterm infants (CME). Transfusion. (2014) 54:627-32:quiz 6. doi: 10.1111/trf.12322

26. Hochart A, Nuytten A, Pierache A, Bauters A, Rauch A, Wibaut B, et al. Hemostatic profile of infants with spontaneous prematurity: can we predict intraventricular hemorrhage development? Ital J Pediatr. (2019) 45:113. doi: 10.1186/s13052-019-0709-8

27. Reverdiau-Moalic P, Delahousse B, Body G, Bardos P, Leroy J, Gruel Y. Evolution of blood coagulation activators and inhibitors in the healthy human fetus. Blood. (1996) 88:900-6. doi: 10.1182/blood.V88.3.900.900

28. Liu J, Dai Y, Yuan E, Li Y, Wang Q, Wang L, et al. Paediatric reference intervals for common coagulation assays in Chinese children as performed on the STA-R coagulation analyzer. Int J Lab Hematol. (2019) 41:697701. doi: 10.1111/ijlh.13098

29. Appel IM, Grimminck B, Geerts J, Stigter R, Cnossen MH, Beishuizen A. Age dependency of coagulation parameters during childhood and puberty. $J$ Thromb Haemost. (2012) 10:2254-63. doi: 10.1111/j.1538-7836.2012.04905.x

30. Liu Q, Xu C, Chen X, Wang J, Ke Z, Hu H. Establishing a reference range for thromboelastograph parameters in the neonatal period. Int J Lab Hematol. (2019) 41:530-5. doi: 10.1111/ijlh.13043

31. Oswald E, Stalzer B, Heitz E, Weiss M, Schmugge M, Strasak A, et al. Thromboelastometry (ROTEM) in children: age-related reference ranges and correlations with standard coagulation tests. Br J Anaesth. (2010) 105:82735. doi: 10.1093/bja/aeq258

32. Sokou R, Foudoulaki-Paparizos L, Lytras T, Konstantinidi A, Theodoraki M, Lambadaridis I, et al. Reference ranges of thromboelastometry in healthy full-term and pre-term neonates. Clin Chem Lab Med. (2017) 55:15927. doi: 10.1515/cclm-2016-0931

33. Theodoraki M, Sokou R, Valsami S, Iliodromiti Z, Pouliakis A, Parastatidou $S$, et al. Reference values of thrombolastometry parameters in healthy term neonates. Children. (2020) 7:259. doi: 10.3390/children7120259

34. Mirabella L, Cotoia A, Colacicco G, Tullo L, Salatto P, Mollica G, et al. Reference values for coagulation assessment in full-term newborns. Minerva Anestesiol. (2017) 83:369-74. doi: 10.23736/S0375-9393.16.11375-6

35. Ignjatovic $\mathrm{V}$, Ilhan $\mathrm{A}$, Monagle $\mathrm{P}$. Evidence for age-related differences in human fibrinogen. Blood Coagul Fibrinolysis. (2011) 22:110-7. doi: 10.1097/MBC.0b013e328343312f

36. Brown AC, Hannan RT, Timmins LH, Fernandez JD, Barker TH, Guzzetta NA. Fibrin network changes in neonates after cardiopulmonary bypass. Anesthesiology. (2016) 124:1021-31. doi: 10.1097/ALN.0000000000001058

37. Parmar N, Albisetti M, Berry LR, Chan AK. The fibrinolytic system in newborns and children. Clin Lab. (2006) 52:115-24.

38. Monagle P, Barnes C, Ignjatovic V, Furmedge J, Newall F, Chan A, et al. Developmental haemostasis. Impact for clinical haemostasis laboratories. Thromb Haemost. (2006) 95:362-72. doi: 10.1160/TH05-01-0047

39. Galas FR, de Almeida JP, Fukushima JT, Vincent JL, Osawa EA, Zeferino $S$, et al. Hemostatic effects of fibrinogen concentrate compared with cryoprecipitate in children after cardiac surgery: a randomized pilot trial. $J$ Thorac Cardiovasc Surg. (2014) 148:1647-55. doi: 10.1016/j.jtcvs.2014.04.029

40. Downey LA, Andrews J, Hedlin H, Kamra K, McKenzie ED, Hanley FL, et al. Fibrinogen concentrate as an alternative to cryoprecipitate in a postcardiopulmonary transfusion algorithm in infants undergoing cardiac surgery: a prospective randomized controlled trial. Anesth Analg. (2020) 130:740-51. doi: 10.1213/ANE.0000000000004384

41. Solomon C, Pichlmaier U, Schoechl H, Hagl C, Raymondos K, Scheinichen $D$, et al. Recovery of fibrinogen after administration of fibrinogen concentrate to patients with severe bleeding after cardiopulmonary bypass surgery. $\mathrm{Br} \mathrm{J}$ Anaesth. (2010) 104:555-62. doi: 10.1093/bja/aeq058 
42. Lee SH, Lee SM, Kim CS, Cho HS, Lee JH, Lee CH, et al. Fibrinogen recovery and changes in fibrin-based clot firmness after cryoprecipitate administration in patients undergoing aortic surgery involving deep hypothermic circulatory arrest. Transfusion. (2014) 54:1379-87. doi: 10.1111/trf.12479

43. Levy JH, Welsby I, Goodnough LT. Fibrinogen as a therapeutic target for bleeding: a review of critical levels and replacement therapy. Transfusion. (2014) 54:1389-405; quiz 8. doi: 10.1111/trf.12431

44. AABB. Chapter 6: Whole blood collection and component processing. In: Fung MK, editor. Technical Manual. 18th ed. Bethesda, MD: AABB (2014). p. 151-4.

45. European Directorate for the Quality of Medicines HealthCare (EDQM) CoE. Guide to the Preparation, Use and Quality Assurance of Blood Components. 20th ed. Strasbourg: European Directorate for the Quality of Medicines and HealthCare (EDQM) CoE (2020).

46. Joint United Kingdom (UK) Blood Transfusion Tissue Transplantation Services Professional Advisory Committee (JPAC). Guidelines for the Blood Transfusion Services in the UK. Chapter 7: Specifications for blood components (2013).

47. Buckley L, Gonzales R. Challenges to producing novel therapies - dried plasma for use in trauma and critical care. Transfusion. (2019) 59:83745. doi: $10.1111 /$ trf. 14985

48. Theusinger OM, Baulig W, Seifert B, Emmert MY, Spahn DR, Asmis LM. Relative concentrations of haemostatic factors and cytokines in solvent/detergent-treated and fresh-frozen plasma. Br J Anaesth. (2011) 106:505-11. doi: 10.1093/bja/aer003

49. Collins PW, Solomon C, Sutor K, Crispin D, Hochleitner G, Rizoli S, et al. Theoretical modelling of fibrinogen supplementation with therapeutic plasma, cryoprecipitate, or fibrinogen concentrate. Br J Anaesth. (2014) 113:585-95. doi: 10.1093/bja/aeu086

50. Kasper CK. Judith Graham Pool and the discovery of cryoprecipitate. Haemophilia. (2012) 18:883-5. doi: 10.1111/hae.12042

51. Nascimento B, Goodnough LT, Levy JH. Cryoprecipitate therapy. Br J Anaesth. (2014) 113:922-34. doi: 10.1093/bja/aeu158

52. Yan MTS, Rydz N, Goodyear D, Sholzberg M. Acquired factor XIII deficiency: a review. Transfus Apher Sci. (2018) 57:72430. doi: 10.1016/j.transci.2018.10.013

53. Gerlach R, Tolle F, Raabe A, Zimmermann M, Siegemund A, Seifert V. Increased risk for postoperative hemorrhage after intracranial surgery in patients with decreased factor XIII activity: implications of a prospective study. Stroke. (2002) 33:1618-23. doi: 10.1161/01.STR.0000017219.83330.FF

54. Listyo S, Forrest E, Graf L, Korte W. The need for red cell support during noncardiac surgery is associated to pre-transfusion levels of FXIII and the platelet count. J Clin Med. (2020) 9:2456-65. doi: 10.3390/jcm9082456

55. Cushing MM, Fitzgerald MM, Harris RM, Asmis LM, Haas T. Influence of cryoprecipitate, Factor XIII, and fibrinogen concentrate on hyperfibrinolysis. Transfusion. (2017) 57:2502-10. doi: 10.1111/trf.14259

56. National Blood Authority (NBA) Australia. National Blood Authority, Annual Report. Canberra ACT (2018-2019).

57. Wong H, Curry N. Do we need cryoprecipitate in the era of fibrinogen concentrate and other specific factor replacement options? ISBT Sci Ser. (2018) 13:23-38 doi: 10.1111/voxs.12376

58. Okerberg CK, Williams LA, 3rd, Kilgore ML, Kim CH, Marques MB, Schwartz J, et al. Cryoprecipitate AHF vs. fibrinogen concentrates for fibrinogen replacement in acquired bleeding patients - an economic evaluation. Vox Sang. (2016) 111:292-8. doi: 10.1111/vox.12417

59. Di Minno G, Navarro D, Perno CF, Canaro M, Gurtler L, Ironside JW, et al. Pathogen reduction/inactivation of products for the treatment of bleeding disorders: what are the processes and what should we say to patients? Ann Hematol. (2017) 96:1253-70. doi: 10.1007/s00277-017-3028-4

60. World Health Organization (WHO). WHO Blood Regulators Network (BRN) Position Statement on Use of Pathogenof bleeding disorders: what are the processes and what should weactor Concentrates are Unavailable or Unaffordable*. Genève (2019).

61. World Federation of Hemophilia. World Federation of Hemophilia Statement on Cryoprecipitate for Treatment of Congenital Bleeding Disorders (2019).

62. Rock G. A comparison of methods of pathogen inactivation of FFP. Vox Sang. (2011) 100:169-78. doi: 10.1111/j.1423-0410.2010.01374.x
63. Cushing MM, Asmis LM, Harris RM, DeSimone RA, Hill S, Ivascu N, et al. Efficacy of a new pathogen-reduced cryoprecipitate stored 5 days after thawing to correct dilutional coagulopathy in vitro. Transfusion. (2019) 59:1818-26. doi: 10.1111/trf.15157

64. Mumford AD, Ackroyd S, Alikhan R, Bowles L, Chowdary P, Grainger J, et al. Guideline for the diagnosis and management of the rare coagulation disorders: a United Kingdom Haemophilia Centre Doctors' Organization guideline on behalf of the British Committee for Standards in Haematology. Br J Haematol. (2014) 167:304-26. doi: 10.1111/bjh.13058

65. Harvey AR, Basavaraju SV, Chung KW, Kuehnert MJ. Transfusion-related adverse reactions reported to the national healthcare safety network hemovigilance module, United States, 2010 to 2012. Transfusion. (2015) 55:709-18. doi: 10.1111/trf.12918

66. Vossoughi S, Perez G, Whitaker BI, Fung MK, Stotler B. Analysis of pediatric adverse reactions to transfusions. Transfusion. (2018) 58:609. doi: 10.1111/trf.14359

67. Kumar R, Sedky MJ, Varghese SJ, Sharawy OE. Transfusion related acute lung injury (TRALI): a single institution experience of 15 years. Indian J Hematol Blood Transfus. (2016) 32:320-7. doi: 10.1007/s12288-015-0604-4

68. Bolton-Maggs PHB. Serious hazards of transfusion - conference report: celebration of 20 years of UK haemovigilance. Transfus Med. (2017) 27:393400. doi: 10.1111/tme.12502

69. Elliot J, Narayan S, Poles D, Tuckley V, Bolton-Maggs, PHB. On behalf of the Serious Hazards of Transfusion (SHOT) Steering Group. The 2019 Annual SHOT Report. United Kingdom (2020).

70. Oakley FD, Woods M, Arnold S, Young PP. Transfusion reactions in pediatric compared with adult patients: a look at rate, reaction type, and associated products. Transfusion. (2015) 55:563-70. doi: 10.1111/trf.12827

71. Sampson J, de Korte D. DEHP-plasticised PVC: relevance to blood services. Transfus Med. (2011) 21:73-83. doi: 10.1111/j.1365-3148.2010.01056.x

72. U.S. Food and Drug Administration. Safety Assessment of Di(2 ethylhexyl)phthalate (DEHP) Released from PVC Medical Devices. Rockville, MD (2001).

73. Franchini M, Lippi G. Fibrinogen replacement therapy: a critical review of the literature. Blood Transfus. (2012) 10:23-7. doi: 10.2450/2011.0015-11

74. CSL Behring Canada Inc. Product Monograph - RiaSTAP ${ }^{\circledR}$ Fibrinogen Concentrate (Human). Available online at: http://labeling.cslbehring.ca/PM/ CA/RiaSTAP/EN/RiaSTAP-Product-Monograph.pdf2019

75. CSL Behring Netherland. Product Monograph: Haemocomplettan P $1 g / 2 g$. Available online at: https://labeling.csl.com/SMPC/NL/Haemocomplettan-P/ NL/Haemocomplettan-P-SPC.pdf2019

76. Sante HAD. CLOTTAFACT $1.5 \mathrm{~g} / 100 \mathrm{ml}$, powder and solvent for solution for injection. LFB-Biomedicaments (2009).

77. Electronic Medicines Compendium (EMC). FibCLOT 1.5 g. Powder and solvent for solution for injection/infusion, LFB Biopharmaceuticals Limited London: LFB Biopharmaceuticals Limited. (2019). Available online at: https:// www.medicines.org.uk/emc/product/2429\#gref

78. Octapharma Canada Inc. Product Monograph including Patient Medication Information. Fibryga, Fibrinogen Concentrate (Human) (2017).

79. Erdoes G, Koster A, Meesters MI, Ortmann E, Bolliger D, Baryshnikova E, et al. The role of fibrinogen and fibrinogen concentrate in cardiac surgery: an international consensus statement from the haemostasis and transfusion scientific subcommittee of the european association of cardiothoracic anaesthesiology. Anaesthesia. (2019) 74:1589-600. doi: 10.1111/anae.14842

80. Acharya SS, Manco-Johnson MJ. Rare Congenital Fibrinogen Deficiencies. (2020). Available online at: http://www.rarecoagulationdisorders.org/ diseases/rare-congenital-fibrinogen-deficiencies/medicationstreatment

81. Schulz PM, Gehringer W, Nohring S, Muller S, Schmidt T, KekeissSchertler S, et al. Biochemical characterization, stability, and pathogen safety of a new fibrinogen concentrate (fibryga((R))). Biologicals. (2018) 52:727. doi: 10.1016/j.biologicals.2017.12.003

82. Haas T, Cushing MM, Asmis LM. Comparison of the efficacy of two human fibrinogen concentrates to treat dilutional coagulopathy in vitro. Scand J Clin Lab Invest. (2018) 78:230-5. doi: 10.1080/00365513.2018.1437645

83. Grottke O, Callum J, Cushing MM, Haas T. The use of coagulation factor concentrates for perioperative bleeding management - a global perspective. Transfusion. (2020) 60:663-6. doi: 10.1111/trf.15749 
84. Compendium EM. FibCLOT 1.5g. Powder and solvent for solution for injection/infusion Summary of Product Characteristics: LFB Biopharmaceuticals Limited. Available online at: https://www.medicines. org.uk/emc/product/2429/smpc\#EXCIPIENTS

85. Solomon C, Groner A, Ye J, Pendrak I. Safety of fibrinogen concentrate: analysis of more than 27 years of pharmacovigilance data. Thromb Haemost. (2015) 113:759-71. doi: 10.1160/TH14-06-0514

86. Hunt BJ, Allard S, Keeling D, Norfolk D, Stanworth SJ, Pendry K, et al. A practical guideline for the haematological management of major haemorrhage. Br J Haematol. (2015) 170:788-803. doi: 10.1111/bjh.13580

87. Goobie SM, Gallagher T, Gross I, Shander A. Society for the advancement of blood management administrative and clinical standards for patient blood management programs. 4th edition (pediatric version). Paediatr Anaesth. (2019) 29:231-6. doi: 10.1111/pan.13574

88. New HV, Berryman J, Bolton-Maggs PH, Cantwell C, Chalmers EA, Davies T, et al. Guidelines on transfusion for fetuses, neonates and older children. $\mathrm{Br} \mathrm{J}$ Haematol. (2016) 175:784-828. doi: 10.1111/bjh.14233

89. National Blood Authority. Patient Blood Management Guidelines: Module 6 Neonates and Paediatrics. Canberra, ACT (2016).

90. Girelli G, Antoncecchi S, Casadei AM, Del Vecchio A, Isernia P, Motta M, et al. Recommendations for transfusion therapy in neonatology. Blood Transfus. (2015) 13:484-97. doi: 10.2450/2015.0113-15

91. National Institute of Health and Care Excellence (NICE). Blood Transfusion. London (2015).

92. AABB. Chapter 2: Facilities, work environment, and safety. In: Fung MK, editor. Technical Manual. 18th ed. Bethesda, MD: AABB (2014). p. 39-81.
93. Barcelona SL, Thompson AA, Cote CJ. Intraoperative pediatric blood transfusion therapy: a review of common issues. Part II: transfusion therapy, special considerations, and reduction of allogenic blood transfusions. Paediatr Anaesth. (2005) 15:814-30. doi: 10.1111/j.1460-9592.2004. 01549.x

94. Raes A, Van Aken S, Craen M, Donckerwolcke R, Vande Walle J. A reference frame for blood volume in children and adolescents. BMC Pediatr. (2006) 6:3. doi: 10.1186/1471-2431-6-3

95. AABB. Chapter 23: Neonatal and pediatric transfusion practice. In: Fung MK, editor. Technical Manual. 18th ed. Bethesda, MD: AABB (2014). p. 578-84

96. Green L, Bolton-Maggs P, Beattie C, Cardigan R, Kallis Y, Stanworth SJ, et al. British Society of Haematology Guidelines on the spectrum of fresh frozen plasma and cryoprecipitate products: their handling and use in various patient groups in the absence of major bleeding. Br J Haematol. (2018) 181:54-67. doi: $10.1111 /$ bjh.15167

Conflict of Interest: The authors declare that the research was conducted in the absence of any commercial or financial relationships that could be construed as a potential conflict of interest.

Copyright (C) 2021 Huisman and Crighton. This is an open-access article distributed under the terms of the Creative Commons Attribution License (CC BY). The use, distribution or reproduction in other forums is permitted, provided the original author(s) and the copyright owner(s) are credited and that the original publication in this journal is cited, in accordance with accepted academic practice. No use, distribution or reproduction is permitted which does not comply with these terms. 